\title{
Os "brasis" de Luiz Ruffato, em Eles eram muitos cavalos: crítica ao discurso de nação à luz de Homi Bhabha.
}

\author{
Eduardo Lopez Chagas \\ Universidade Federal de Pelotas \\ Pelotas, Brasil \\ Recebido em: 30/04/2019 \\ Aceito em: 10/06/2019
}

Resumo: Este artigo busca analisar a obra literária Eles eram muitos cavalos, de Luiz Ruffato e o diálogo dela com a crítica de Homi Bhabha ao discurso de nação. Considerando, tal qual Benedict Anderson, a nação como comunidade imaginada, o estudo parte do papel desempenhado pela literatura brasileira na consolidação de um discurso nacional, a partir da sua primeira geração romântica. Nesse sentido, a obra de Ruffato é compreendida como uma antítese ao defendido pelo romantismo, tendo na heterogeneidade uma de suas principais características, no que estabelece profunda relação com a ideia de discurso de nação defendida por Homi Bhabha.

Palavras-Chave: Nação. Romantismo. Literatura nacional.

\begin{abstract}
This paper aims to analyze the literaly work Eles eram muito cavalos, by the author Luis Ruffato, and the relation between this book with Homi Bhabha's critique of the discourse of nation. Considering, such as Benedict Anderson, the nation as an imagined community, this study starts from the role of Brazilian Literature in the consolidation of discourse of nation, from its first romantic generation. In this sense, the literaly work written by Ruffato is understood as an antithesis defended by the romantism, it has in heterogeneity one of the most important features and it establishs a deep relation with discourse of nation's idea, which is defended by Homi Bhabha.
\end{abstract}

Key-words: Nation. Romanticism. National literature.

Resumen: Este artículo busca analizar la obra literaria Eles eram muitos cavalos, de Luiz Ruffato y el diálogo de la misma con la crítica de Homi Bhabha al discurso de nación. Considerando, tal cual Benedict Anderson, la nación como comunidad imaginada, el estudio parte del papel desempeñado por la literatura brasileña en la consolidación de un discurso nacional, a partir de su primera generación romántica. En este sentido, la obra de Ruffato es comprendida como una antítesis al defendido por el romanticismo, teniendo en la heterogeneidad una de sus principales características, en el que establece profunda relación con idea de discurso de nación defendida por Homi Bhabha.

Palabras-Clave: Nación. Romanticismo. Literatura nacional. 


\section{Introdução}

Em 1882, Ernest Renan proferiu uma conferência na Sorbonne onde se perguntava $O$ que é uma nação? O ensaio é considerado por muitos como fundamental para qualquer discussão que se faça acerca dos temas nação e nacionalismo, e nele Renan busca ampliar o horizonte da análise, evitando assim respostas de cunho imediatista, como as que buscavam definir uma nação em virtude da raça, da língua, da religião, de uma comunidade de interesses ou mesmo da geografia do lugar.

Para Renan, “A nação moderna é, então, um resultado histórico levado a termo por uma série de fatos convergentes no mesmo sentido" (RENAN, 1882, p. 7), ou seja, é o resultado de questões políticas, sociais e econômicas muito peculiares, daí a heterogeneidade com que se dão os respectivos processos de sua construção e consolidação. Ele ratifica essa ideia pontuando as características díspares que envolveram a formação de nações como a França, a Holanda ou a Suíça, por exemplo.

Apesar das especificidades envolvendo cada processo de construção de uma nação, e por mais distintas que elas se tornem, ainda assim elas guardarão duas características em comum: a primeira delas é a violência que permeia todos os processos de formação nacional. "A unidade se faz sempre brutalmente" (RENAN, 1882, p. 5-6). A segunda característica em comum é que a violência envolvida na gênese de uma nação precisa ser esquecida. “Ora, a essência de uma nação é que todos os indivíduos tenham muitas coisas em comum, e também que todos tenham esquecido coisas" (RENAN, 1882, p. 6).

Considerando que violência e esquecimento são características comuns e intrínsecas a todas as nações, o que realmente a constitui? O que é, de fato, uma nação? Para Renan,

Uma nação é uma alma, um princípio espiritual. Duas coisas que para dizer a verdade não formam mais que uma, constituem esta alma, este princípio espiritual. Uma está no passado, a outra no presente. Uma é a possessão em comum de um rico legado de lembranças; outra é o consentimento atual, o desejo de viver em conjunto, a vontade 
continuar a fazer valer a herança que receberam esses indivíduos. $\mathrm{O}$ homem, Senhores, não se improvisa. A nação, como o indivíduo, é o resultado de um longo processo de esforços, de sacrifícios e de devotamentos. O culto dos ancestrais é de todos o mais legítimo; os ancestrais nos fizeram o que nós somos. Um passado heroico, dos grandes homens, da glória (eu entendo da verdadeira), eis o capital social sobre o qual se assenta uma ideia nacional (RENAN, 1882, p. 18).

Apesar da construção histórica feita por Renan para refutar algumas considerações apressadas acerca do termo "nação", sua definição, alicerçada em uma "alma”, em um "princípio espiritual" soa de forma vaga e imprecisa. Se por um lado ele afasta definições objetivas acerca do termo "nação", como língua, religião ou mesmo território, por outro resvala em uma concepção subjetiva na hora de defini-la.

Eric Hobsbawm discorre sobre a dificuldade em conceituar o que é uma "nação" com base em definições subjetivas ou objetivas, dizendo que nem uma nem outra "são satisfatórias, e ambas são enganosas" (HOBSBAWM, 1990, p. 18) e aponta o "agnosticismo" (HOBSBAWM, 1990, p. 18) como a melhor alternativa aos que se debruçam sobre esse tema. Porém, ainda que não apresente uma definição precisa, Hobsbawm tece algumas considerações importantes, por exemplo, ao citar o trabalho de Ernest Gellner, enfatiza "o elemento do artefato, da invenção e da engenharia social que entra na formação das nações" (HOBSBAWM, 1990, p. 19), de forma que para ele “[...] o nacionalismo vem antes das nações. As nações não formam os Estados e os nacionalismos, mas sim o oposto" (HOBSBAWM, 1990, p. 19).

O aspecto da "invenção" está presente na formulação proposta por Benedict Anderson quando esse conceitua a nação como uma "comunidade política imaginada - e imaginada como implicitamente limitada e soberana” (ANDERSON, 1989, p. 14), e especifica que ela é “imaginada”, pois, por menor que seja, jamais seus membros se conhecerão de fato, ainda que alimentem a “imagem de sua comunhão" (ANDERSON, 1989, p. 14), é "limitada” porque não é plausível imaginar que um dia todos os indivíduos venham a se reunir sob uma única e mesma nação, é "soberana" pois o baluarte da liberdade a que almejam está consubstanciado no "Estado soberano" (ANDERSON, 1989, p. 16), mas, sobretudo, 
Finalmente, a nação é imaginada como comunidade porque, sem considerar a desigualdade e exploração que atualmente prevalecem em todas elas, a nação é sempre concebida como um companheirismo profundo e horizontal. Em última análise, essa fraternidade é que torna possível, no correr dos últimos dois séculos, que tantos milhões de pessoas, não só matem, mas morram voluntariamente por imaginações tão limitadas (ANDERSON, 1989, p. 16).

Se a nação é mesmo imaginada como preceitua Anderson, e imaginada enquanto comunidade, talvez seja fundamental ter em mente "por quem" e "para quem” ela é imaginada. Nesse sentido, Hobsbawm esclarece que, para além de existirem como "um tipo particular de Estado territorial ou da aspiração de assim se estabelecer" (HOBSBAWM, 1990, p. 19), as nações existem "também no contexto de um estágio particular do desenvolvimento econômico e tecnológico" (HOBSBAWN, 1990, p. 19).

As nações e seus fenômenos associados devem, portanto, ser analisados em termos das condições econômicas, administrativas, técnicas, políticas e outras exigências; por essa razão as nações são, do meu ponto de vista, fenômenos duais, construídos essencialmente pelo alto, mas que, no entanto, não podem ser compreendidas sem ser analisadas de baixo, ou seja, em termos das suposições, esperanças, necessidades, aspirações e interesses das pessoas comuns, as quais não são necessariamente nacionais e menos ainda nacionalistas (HOBSBAWM, 1990, p. 19).

Dessa forma, tem-se que as nações não surgem per si, como que de forma etérea. Elas são resultado de processos políticos e sociais específicos, que estão imbricados a específicos processos econômicos e tecnológicos, ou seja, a nação, como resultado dessa conjuntura, também parece ser o resultado dos interesses daqueles que comandam essas respectivas áreas, os "de cima”, conforme Hobsbawm, que direta ou indiretamente, definem os rumos dos "de baixo".

A dualidade entre os "de cima" e os "de baixo", e as distintas maneiras de narrar a nação, a partir da perspectiva de um ou de outro, vão ao encontro do proposto por Homi Bhabha em seu ensaio DissemiNação (2010), e que servirá mais adiante de aporte teórico para a análise desenvolvida neste artigo.

Dentro do processo de "narrar" a nação, coube à literatura um papel preponderante, principalmente ao longo do Século XIX. No caso do Brasil, isso se 
torna ainda mais evidente ante o esforço feito para dotar o país de uma literatura verdadeiramente nacional, principalmente após a Independência do país em 1822 . Que nação era essa que devia ser narrada? Qual o papel da literatura dentro desse processo? Trazendo essas questões para o século XXI, qual nação é narrada dentro da obra Eles eram muitos cavalos, de Luiz Ruffato? Seguirá ele os ensinamentos da primeira geração romântica do Brasil?

\section{Desenvolvimento}

Em Formação da literatura brasileira (2000), no capítulo dedicado ao "nacionalismo literário", Antonio Candido avalia que o movimento árcade no Brasil representou a "incorporação da atividade intelectual aos padrões europeus tradicionais, ou seja, a um sistema expressivo, segundo o qual se havia forjado a literatura do Ocidente" (CANDIDO, 200o, p. 339). Para ele, isso significava

[...] praticar a literatura, ao mesmo tempo, como atividade desinteressada e como instrumento, utilizando-a ao modo de um recurso de valorização do país - quer no ato de fazer aqui o mesmo que se fazia na Europa culta, quer exprimindo a realidade local (CANDIDO, 2000, p. 339).

E é justamente na maneira de "exprimir a realidade local" que a literatura ajudou a narrar a nação brasileira, principalmente a partir de 1822 , quando da Independência do país. É como se a ruptura política entre metrópole e colônia necessitasse se dar também no plano literário, com a sublimação de elementos que singularizassem o "novo" país, daí as odes às belezas naturais, aos costumes e às tradições, bem como o papel central conferido ao indígena na construção dessa literatura verdadeiramente "nacional".

Que se entendia por semelhante coisa? Para uns era a celebração da pátria, para outros o indianismo, para outros, enfim, algo indefinível, mas que nos exprimisse. Ninguém saberia dizer com absoluta precisão; mas todos tinham uma noção aproximada, que podemos avaliar lendo as várias manifestações a respeito, algumas bastante compreensivas 
para abranger vários ou todos os temas reputados nacionais (CANDIDO, 2000, p. 339).

Nesse sentido, o Romantismo no Brasil transformou-se em grande aliado do nacionalismo, não que alguns de seus temas não estivessem presentes também no período árcade, mas assumiam agora uma nova configuração.

A Independência importa de maneira decisiva no desenvolvimento da idéia romântica, para a qual contribuiu pelo menos com três elementos que se podem considerar como redefinição de posições análogas do Arcadismo: (a) desejo de exprimir uma nova ordem de sentimentos, agora reputados de primeiro plano, como o orgulho patriótico, extensão do antigo nativismo; (b) desejo de criar uma literatura independente, diversa, não apenas uma literatura, de vez que, aparecendo o Classicismo como manifestação do passado colonial, o nacionalismo literário e a busca de modelos novos, nem clássicos nem portugueses, davam um sentimento de libertação relativamente à mãe-pátria; finalmente (c) a noção já referida de atividade intelectual não mais apenas como prova de valor do brasileiro e esclarecimento mental do país, mas tarefa patriótica na construção nacional (CANDIDO, 200o, p. 340).

Candido destaca que, apesar de aliados, “Teoricamente, o nacionalismo independe do Romantismo" (CANDIDO, 2000, p. 343), pois suas ideias teriam se desenvolvido em "formas não-românticas" (CANDIDO, 200o, p. 343), de forma que

O Romantismo brasileiro foi por isso tributário do nacionalismo; embora nem todas as suas manifestações concretas se enquadrassem nele, ele foi o espírito diretor que animava a atividade geral da literatura. Nem é de espantar que assim fosse, pois sem falar da busca das tradições nacionais e o culta da história, o que se chamou em toda a Europa "despertar das nacionalidades", em seguida ao empuxe napoleônico, encontrou expressão no Romantismo. Sobretudo nos países novos e nos que adquiriram ou tentaram adquirir independência, o nacionalismo foi manifestação de vida, exaltação afetiva, tomada de consciência, afirmação do próprio contra o imposto (CANDIDO, 2000, p. 343).

Marco importante nesse período é a publicação da Niterói, Revista Brasiliense de Ciências, Letras e Artes que, sob a "intuição decisiva" (CANDIDO, 200o, p. 341) de Domingos José Gonçalves de Magalhães, conferiu às "novas orientações literárias" (CANDIDO, 200o, p. 341) o papel de "definir uma literatura nova no Brasil, que fosse no plano da arte o que fora a Independência na vida 
política e social" (CANDIDO, 2000, p. 341). O primeiro parágrafo do manifesto escrito por Magalhães, e publicado na revista Niterói, deixa claro o que pensava seu autor sobre o papel da literatura de um país.

\begin{abstract}
A literatura de um povo é o desenvolvimento do que ele tem de mais sublime nas idéias, de mais filosófico no pensamento, de mais heroico na moral e de mais belo na natureza; é o quadro animado de suas virtudes e de suas paixões, o despertador de sua glória e o reflexo progressivo de sua inteligência. E, quando esse povo, ou essa geração, desaparece da superfície da terra, com todas as suas instituições, crenças e costumes, escapa a literatura aos rigores do tempo para anunciar às gerações futuras qual fora o caráter e a importância do povo, do qual é ela o único representante na posteridade (MAGALHÃES, 1836, p. 1).
\end{abstract}

O cerne da questão parece ser a literatura como registro à posteridade das ideias, dos costumes e das tradições da sociedade da época, a fim de que o futuro conheça o passado que um dia já foi presente. "Nós pertencemos ao futuro, como o passado nos pertence. A glória de uma Nação que existe, ou que já existiu, não é senão o reflexo da glória de seus grandes homens" (MAGALHÃES, 1836, p. 3). Na defesa acalorada da nação, Magalhães questiona se o conhecimento das obras de autores nacionais está no mesmo patamar da de outros nomes, e define que o papel da literatura é trabalhar para o engrandecimento do país.

\footnotetext{
Não pretendemos que a esmo se louve tudo o que nos pertence, só porque é nosso; vaidade fora insuportável. Mas por ventura vós que consumiste vossa mocidade no estudo dos clássicos latinos e gregos, vós que ledes Racine, Voltaire, Camões ou Felinto Elíseo e não cessais de admirá-los, muitas vezes mais por imitação que por própria crítica, dizei-me: apreciastes vós as belezas naturais de um Santa Rita Durão, de um Basílio da Gama e de um Caldas?

Toca ao nosso século restaurar as ruínas e reparar as faltas dos passados séculos. Cada Nação livre reconhece hoje mais que nunca a necessidade de marchar. Marchar para uma Nação é engrandecer-se moralmente, é desenvolver todos os elementos da civilização (MAGALHÃES, 1836, p. 5).
}

Quase quarenta anos depois do manifesto publicado por Domingos José Gonçalves de Magalhães na revista Niterói, Machado de Assis retoma o assunto, recolocando-o em outros termos. Desta vez não se trata de dizer o que é nacional, mas pontuar de que não basta falar de índios, árvores e pássaros para sê-lo, e 
chega a citar o caso de algumas obras de William Shakespeare, incontestavelmente um escritor inglês, a despeito de muitas de suas obras terem como cenário outros países europeus. Para Machado, "O que se deve exigir do escritor antes de tudo, é certo sentimento íntimo, que o torne homem do seu tempo e do seu país, ainda quando trate de assuntos remotos no tempo e no espaço" (ASSIS, 1873, p. 3).

Machado faz um balanço da cultura brasileira, incluindo aí a poesia e o teatro, apontando defeitos e qualidades, avanços e recuos. Sobre o romance brasileiro, dirá que suas "tendências morais [...] são geralmente boas" (ASSIS, 1873, p. 4) e que apesar da boa aceitação entre o público da literatura francesa, não se percebe na literatura brasileira "tendências para adotar as suas doutrinas" (ASSIS, 1873, p. 4) e vai além, "Isento por esse lado o romance brasileiro, não menos o está de tendências políticas, e geralmente de todas as questões sociais, o que não digo por fazer elogio, nem ainda censura, mas unicamente para atestar o fato" (ASSIS, 1873 , p. 4).

A observação de Machado de Assis sobre a ausência de temas políticos e sociais no romance brasileiro, quarenta anos depois do lançamento da revista Niterói, base das diretrizes literárias que norteariam o romantismo no Brasil, parece lançar luz sobre o projeto de nação a ser narrado a partir desse período. $\mathrm{O}$ fato sui generis de a revista Niterói ser lançada em Paris, por jovens brasileiros que estudavam na França, é outro indicativo sobre quem pensava e para quem era pensada a verve nacionalista da literatura brasileira ao longo do século XIX.

Se o romance brasileiro ao longo do Oitocentos foi elaborado em torno da defesa dos valores patrióticos, Eles eram muitos cavalos (2013), de Luiz Ruffato, publicado originalmente mais de um século e meio depois do manifesto de Domingos José Gonçalves de Magalhães, ressoa como uma espécie de antítese ao apregoado pela primeira geração romântica da literatura brasileira. Ao invés de índios e belezas naturais, o cinzento, o concreto, o barulho, o ritmo irrefreável da São Paulo gigantesca e tentacular, que se espalha, se esparrama em um horizonte de prédios, ruídos... e de gentes. E é dessas gentes, anônimas, que (sobre)vivem às margens, nas franjas da metrópole, que se ocupa a obra de Luiz Ruffato. 
Nesse sentido, o título da obra, antes hermético, torna-se esclarecedor: “muitos", pronome indefinido, refere-se à quantidade, à profusão. "Cavalos”, em sentido denotativo, "mamífero quadrúpede, de um só casco em cada pé (solípede)". Em sentido conotativo, “pessoa grosseira, estúpida, cavalgadura”, sendo cavalgadura, em sentido real, “animal de cavalgar”. Esse é o enredo de Eles eram muitos cavalos: várias histórias anônimas de "animais de cavalgar", de "cavalgados".

Ao trazer para o centro do romance aqueles que, na epígrafe Pedagogia do oprimido (1983), Paulo Freire chama de os "esfarrapados do mundo" (FREIRE, 1983, p. 17), Ruffato faz com que as narrativas transcendam o espaço físico de São Paulo, e tornem-se o espelho de outras tantas vozes anônimas presentes no espaço urbano de pequenas, médias e grandes cidades. Isso porque a senhora nordestina que vem visitar o filho e os netos poderia desembarcar em São Paulo ou em outra rodoviária qualquer, a imundície do barraco dividido por crianças, ratos e uma mãe "que geme baixinho num canto, o branco-dos-olhos arreganhado sob o vaivém de um corpo magro e tatuado, mais um nunca antes visto" (RUFFATO, 2013, p. 20) é mesma em tantas outras cidades e a “Chacina no 41" (RUFFATO, 2013, p. 26) há muito deixou de acontecer apenas em São Paulo.

Dessa forma, ao fazer emergir vozes do subterrâneo das cidades, a obra de Ruffato choca-se com o preceituado pelo romantismo brasileiro, e vai ao encontro de Homi Bhabha quando esse, sem ter no "nacionalismo" seu interesse principal, opõe-se “à certeza histórica e à natureza estável desse termo" (BHABHA, 1998, p. 199) e diz que procura,

[...] escrever sobre a nação ocidental como uma forma obscura e ubíqua de viver a localidade da cultura. Essa localidade está mais em torno da temporalidade do que sobre a historicidade: uma forma de vida que é mais complexa que "comunidade", mais simbólica que "sociedade", mais conotativa que "país", menos patriótica que patrie, mais retórica que a razão de Estado, mais mitológica que a ideologia, menos homogênea que a hegemonia, menos centrada que o cidadão, mais coletiva que "o sujeito", mais psíquica do que a civilidade, mais híbrida na articulação de diferenças e identificações culturais do que pode ser representado em qualquer estruturação hierárquica ou binária do antagonismo social (BHABHA, 1998, p. 199). 
Ao enfocar na "temporalidade" de se tentar ver a nação como uma forma de "viver a localidade da cultura", Bhabha critica o historicismo que tem prevalecido nas discussões sobre a nação, e defende "a representação da nação como processo temporal" (BHABHA, 1998, p. 202). Bhabha apoia sua argumentação sobre o tempo duplo e cindido, que revela a heterogeneidade suplantada pela narração monolítica da nação, citando, por exemplo, as distintas narrativas nacionais que envolvem "as visões de mundo de senhor e escravo, diametralmente opostas entre si, que respondem pela mais importante dialética histórica e filosófica dos tempos modernos" (BHABHA, 1998, p. 205).

Dessa forma, o tempo duplo e cindido proposto por Bhabha traz a marca do heterogêneo e coloca-se em um polo diametralmente oposto ao cimento coesivo pretendido pelo discurso de nação. De acordo com Sérgio Luiz Prado Bellei,

O conceito de nação, pensado tradicionalmente em termos de identidade e essencialidade, pode, e talvez deva, ser pensado hoje em termos de multiplicidade e hibridismo. É que o momento histórico da segunda metade do século atual, marcado, de um lado, pela memória de "identidade", "essencialidade" e "nação" enquanto conceitos também associados às formas de imperialismo cultural e, de outro, pela crescente força dispersiva da globalização que se expressa cada vez mais como fragmentação cultural e proliferação de diferenças, ia aos poucos tornando necessário um pensamento alternativo para a questão da identidade nacional. A nação começa assim a ser pensada, em Benedict Anderson, por exemplo, mais como uma narrativa cultural imaginada e imaginária do que como fato histórico a ser simplesmente aceito, e, em Homi Bhabha, mais como dispersão e hibridismo do que como identidade monolítica (BELLEI, 1998, p. 45).

As análises de Stuart Hall também vão ao encontro do múltiplo quando, valendo-se de Benedict Anderson, aborda "As culturas nacionais como comunidades imaginadas" (HALL, 2006, p. 47). Segundo ele,

No mundo moderno, as culturas nacionais em que nascemos se constituem em uma das principais fontes de identidade cultural. Ao nos definirmos, algumas vezes dizemos que somos ingleses, gauleses ou jamaicanos. Obviamente, ao fazer isso estamos falando de forma metafórica. Essas identidades não estão literalmente impressas em nossos genes. Entretanto, nós efetivamente pensamos nelas como se fossem parte de nossa natureza essencial (HALL, 2006, p. 47). 
O argumento defendido por Hall é de que "as identidades nacionais não são coisas com as quais nós nascemos, mas são formadas e transformadas no interior da representação" (HALL, 2006, p. 48). Para Hall,

\begin{abstract}
As culturas nacionais são uma forma. A lealdade e a identificação que, numa era pré-moderna ou em sociedades mais tradicionais, eram dadas à tribo, ao povo, à religião ou à região, foram transferidas, gradualmente, nas sociedades ocidentais, à cultura nacional. As diferenças regionais e étnicas foram gradualmente sendo colocadas, de forma subordinada, sob aquilo que Gellner chama de "teto político" do estado-nação, que se tornou, assim, uma fonte poderosa de significados para as identidades culturais modernas (HALL, 2006, p. 49).
\end{abstract}

Essa "transferência” de lealdade e identificação apontada por Hall foi - e é - construída não só por instituições culturais, mas também por símbolos, ritos, mitos e representações, que ao formar sentidos, formam também identidades. "Uma cultura nacional é um discurso - um modo de construir sentidos que influencia e organiza tanto nossas ações quanto a concepção que temos de nós mesmos" (HALL, 2006, p. 50).

Após apontar alguns elementos presentes na construção do conceito de cultura nacional, Hall aponta as fissuras presentes nessa construção discursiva, enfatizando, entre outros pontos, a violência e a "supressão forçada da diferença cultural” (HALL, 2006, p. 59) que constituem os processos de unificação nacional, e as "diferentes classes sociais e diferentes grupos étnicos e de gênero" (HALL, 2006, p. 6o) que compõe as nações, citando o esforço feito pelo nacionalismo britânico para suprimir essas diferenças e divisões sociais aportando "um ponto alternativo de identificação - pertencimento comum à ‘família da nação”' (HALL, 2006, p. 61).

Para dizer de forma simples: não importa quão diferentes seus membros possam ser em termos de classe, gênero ou raça, uma cultura nacional busca unificá-los numa identidade cultural, para representálos todos como pertencendo à mesma e grande família nacional (HALL, 2006, p. 59).

É justamente essa multiplicidade de classes, gêneros e raças, suplantada pela égide do discurso nacional, que está presente na obra de Ruffato. Seus 
“cavalos" espelham o cotidiano prosaico de vidas absolutamente díspares, mas que se estruturam sobre o ponto comum do fracasso, da desilusão. Através de personagens anônimas e descrição específica de pequenos detalhes, emergem narrativas que corroem a "grande família nacional".

Dessa forma, emergem narrativas como a do ladrão que quer comprar um presente para a mãe, do homem de classe média que imagina a amizade que poderia ter tido com o vizinho se ele não tivesse sido assassinado em um sequestro relâmpago, dos faxineiros que limpam o sangue da calçada depois da queda de dois operários que limpavam os vidros de um edifício, ou a do segurança "negro agigantado, espadaúdo, impecável dentro do terno preto" e a do "negro franzino, ossudo, camisa de malha branca surrada calça jeans imundo tênis de solado gasto" (RUFFATO, 2013, p. 48).

Intercalando narrativas, ora em primeira, ora em terceira pessoa, inserindo fragmentos de anúncios de emprego, orações e até mesmo um diploma da "Igreja do Evangelho Quadrangular" (RUFFATO, 2013, p. 95), Ruffato subverte a forma convencional em que se estrutura o gênero romance, valendo-se também de uma escrita crua e direta. Sobre a maneira como o romance está estruturado, Fabiana Carneiro da Silva aponta que,

A falta de unidade no foco narrativo e na estrutura do livro - que é composta por fragmentos intitulados, acabados em si mesmos, dispostos de modo não linear e sem relação alguma de causalidade - foi entendida como um fator problemático na concepção do livro como um romance (SILVA, 2009, p. 1-2).

Ademais, apesar de apontar argumentos que justificam a classificação de Eles eram muitos cavalos (2013) como um romance, Fabiana afirma que esse enquadramento da obra ainda é passível de discussão.

De certa maneira, Eles eram muitos cavalos (2013) parece operar como a materialização do definhamento previsto por Walter Benjamin, quando discutia “a natureza da verdadeira narrativa” (BENJAMIN, 2016, p. 200).

Ela tem sempre em si, às vezes de forma latente, uma dimensão utilitária. Essa utilidade pode consistir seja num ensinamento moral, seja numa sugestão prática, seja num provérbio ou numa norma de vida 
- de qualquer maneira, o narrador é um homem que sabe dar conselhos. Mas se "dar conselhos” parece hoje algo de antiquado, é porque as experiências estão deixando de ser comunicáveis. Em consequência, não podemos dar conselhos nem a nós mesmos nem aos outros. Aconselhar é menos responder a uma pergunta que fazer uma sugestão sobre a continuação de uma história que está sendo narrada. Para obter essa sugestão, é necessário primeiro saber narrar a história (sem contar que um homem só é receptivo a um conselho na medida que verbaliza a sua situação). O conselho tecido na substância viva da existência tem um nome: sabedoria. A arte de narrar está definhando porque a sabedoria - o lado épico da verdade - está em extinção (BENJAMIN, 2016, p. 200).

Não há sabedoria em Eles eram muitos cavalos (2013). Não há conselhos. O narrador multifacetado imprime um ritmo veloz às fragmentadas narrativas que, uma a uma, vão perfazendo mais um dia comum na grande metrópole. Ladrões, prostitutas, taxistas, anúncios de emprego, corruptos, estante de livros, infidelidade, salmos, oração para Santo Expedito, casamentos que definham, crianças que são exploradas, eis o discurso de nação apresentado por Ruffato. A obra literária parece encontrar novamente as análises de Homi Bhabha sobre os povos migrantes do mundo contemporâneo,

\begin{abstract}
A esta altura devo ceder à vox populi: a uma tradição relativamente impronunciada dos povos do pagus - colonizados, pós-colonizados, migrantes, minorias - povos errantes que não serão contidos dentro do Heim da cultura nacional e seu discurso uníssono, mas que são eles mesmos os marcos de uma fronteira móvel, que aliena as fronteiras da nação moderna. São, segundo Marx, o exército reserva de trabalho migrante que, ao falar a estrangeiridade da língua, cliva a voz patriótica da unissonância e se torna o exército móvel de metáforas, metonímias e antropomorfismo de Nietzsche. Eles articulam a morte-em-vida da idéia da "comunidade imaginada" da nação (BHABHA, 1998, p. 231).
\end{abstract}

Os migrantes de Bhabha reúnem-se "às margens de culturas 'estrangeiras"” (BHABHA, 1998, p. 198),

[...] reunindo-se nas fronteiras, reuniões nos guetos ou nos cafés de centros de cidade; reunião na meia-vida, meia-luz de línguas estrangeiras, ou na fluência da língua do outro; reunindo os signos de aprovação e aceitação, títulos, discursos, disciplinas, reunindo as memórias de subdesenvolvimento, de outros mundos vividos retroativamente; reunindo o passado num ritual de revivescência, reunindo o presente (BHABHA, 1998, p. 198). 
É possível estabelecer um paralelo entre os migrantes de que fala Bhabha e as personagens de Luiz Ruffato. As narrativas presentes na obra literária reverberam as vivências daqueles que, tais quais os migrantes, vivem à margem, mas não de uma cultura estrangeira, vivem à margem da "própria" cultura nacional, que ao ignorá-los, transforma-os em exilados. Exilados social e economicamente, exilados da cultura nacional, exilados da literatura, exilados do discurso de nação.

À nação homogênea, monolítica, Bhabha advoga uma visão híbrida, aberta, que tenha trânsito com as narrativas propostas por diferentes atores. Segundo Sérgio Luiz Prado Bellei,

\begin{abstract}
Parece-me que, ao reescrever Derrida ressaltando, através do "N" maiúsculo, o conceito de nação enquanto parte inseparável do conceito de disseminação, Bhabha propõe que estes conceitos sejam pensados não em termos de uma lógica de "ou um ou outro", como ocorre em Schlesinger, mas em termos de uma lógica de "tanto um como o outro", ou seja, uma lógica de inclusão mútua, não totalizante, e problemática em contraste com uma lógica de exclusão simplificadora (BELLEI, 1998, p. 47).
\end{abstract}

No Brasil, o período romântico se encarregou de operar a "exclusão simplificadora", pautando a literatura brasileira por um indianismo que buscava revesti-la de um caráter especificamente nacional. Sobre isso, Antonio Candido diz que,

\begin{abstract}
As suas origens são óbvias: busca do específico brasileiro, já orientada neste sentido (com meia consciência do problema) pelos poemas de Durão e Basílio e as metamorfoses de Diniz, além duma crescente utilização alegórica do aborígine na comemoração plástica e poética. [...] O processo se intensifica a partir da Independência, pela adoção de nomes e atribuição de títulos indígenas: pela identificação do selvagem ao brio nacional e o seu aproveitamento plástico (CANDIDO, 200o, p. 18).
\end{abstract}

Mais adiante, Candido rebate a posição de Capistrano de Abreu, para quem o indianismo refletia profunda tendência popular, e sugere que, "ao contrário, que tal identificação provém de fonte erudita, a utilização nativista do índio é que se projetou na consciência popular" (CANDIDO, 200o, p. 18). 
Utilizado pela elite literária como símbolo da nova nação, o indianismo foi uma das estratégias adotadas ao longo do romantismo para dotar o país de uma literatura e de um discurso genuinamente nacionais.

Um século e meio depois, a obra de Ruffato caminha no sentido oposto às loas feitas em defesa da nação. Nela, as palmeiras e os sabiás, de Gonçalves Dias, foram asfaltados, e assumiram o tom cinzento dos prédios e o ruído infernal das ruas de São Paulo, e o índio, que no romantismo foi visto como "elemento básico da sensibilidade patriótica” (CANDIDO, 2000, p. 19),

[...] toda gente sabe é que um final de tarde o bugre apareceu no boteco, encostou a pança careca no balcão de fórmica vermelha ensebado, pediu uma cachaça na língua enrolada lá dele, alguém viu graça, bancou o prejuízo, e o selvagem, noite adentro, tornando-se alegre, foi para o meio do asfalto dançar, e os sem juízo cercaram ele numa roda batendo palmas, o bicho entusiasmou, arrancou a roupa sob aplausos do povaréu, ficou balangando os negócios, crianças e mulheres passando, e juntou vagabundo e trabalhador, a arruaça contagiou aquele canto do bairro, uma esbórnia. Até que alguém, sempre um desmancha-prazeres, convocou a polícia. Veio a Rota, sirene esgoelando, pneus solfejando, os peemes desembarcaram distribuindo sarrafo sem piedade nem dó, e o povinho ralo, sebo nas canelas, sumiu num trovoar, os deixa-disso quisemos explicar, aquilo era índio, índio mesmo, de verdade, portanto os troços de fora, mas os cassetetes nem a, miraram no lombo da negada, e o peri lá, sozinho, pelado bêbado, débil. Agarrado, algemado, arremessado, mofou no fundo de uma cela (RUFFATO, 2013, p. 29).

Ele reaparece no mesmo boteco, faminto, sem dinheiro, limpa o banheiro, os copos e a pia em troca de comida, dorme sob a marquise na porta do bar, capina pátio, leva recado, toma cerveja, come churrasco e feijoada e ao saber da morte de Seu Aprígio, o dono do bar,

[...] murcho e sozinho, desfiou as ruas pobres do Jardim Varginha, garrafa de cachaça debaixo do sovaco. Houve quem tenha visto seus passos cambaleantes empurrarem-no ao encontro da noite áspera, mas só a manhã surpreendeu o índio esticado sob a marquise de uma loja de material-de-construção na Avenida Santo Amaro, abraçado a um casco branco vazio, a tudo alheio, a tudo (RUFFATO, 2013, p. 30).

O índio de Ruffato é diametralmente oposto ao pretendido pela geração romântica de Magalhães. Frágil, humano, apresenta-se despido do aspecto de 
guerreiro mítico, portador de valores idealizados sobre o caráter da nação, pretendido e construído ao longo do período romântico da literatura brasileira.

\section{Conclusão}

Stuart Hall conclui seu exame das culturas nacionais como comunidades imaginadas dizendo que "As identidades nacionais não subordinam todas as outras formas de diferença e não estão livres do jogo de poder, de divisões e contradições internas, de lealdades e de diferenças sobrepostas" (HALL, 2006, p. 65). Para ele,

Em vez de pensar as culturas nacionais como unificadas, deveríamos pensá-las como constituindo um dispositivo discursivo que representa a diferença como unidade ou identidade. Elas são atravessadas por profundas divisões e diferenças internas, sendo "unificadas" apenas através do exercício de diferentes formas de poder cultural. Entretanto - como na fantasia do eu "inteiro" de que fala a psicanálise lacaniana as identidades nacionais continuam a ser representadas como unificadas (HALL, 2006, p. 62).

Ao longo do Século XIX, a literatura brasileira, através dos preceitos defendidos pelo romantismo, se prestou ao papel de tentar unificar a cultura nacional, limpando-a de arestas inconvenientes, como, no plano político, ser a única monarquia em uma América sacudida pelos efeitos da Revolução Francesa do final do Século XVIII, e, principalmente, no plano social e econômico, a manutenção e ampliação da escravização humana. A incongruência desse cenário é captada por Roberto Schwarz,

Toda ciência tem princípios, de que deriva o seu sistema. Um dos princípios da Economia Política é o trabalho livre. Ora, no Brasil domina o fato "impolítico e abominável" da escravidão. Este argumento - resumo de um panfleto liberal, contemporâneo de Machado de Assis - põe fora o Brasil do sistema da ciência. Estávamos aquém da realidade a que esta se refere: éramos antes um fato moral, "impolítico e abominável". Grande degradação, considerando-se que a ciência eram as Luzes, o Progresso, a Humanidade etc. Para as artes, Nabuco expressa um sentimento comparável quando protesta contra o assunto 
escravo no teatro de Alencar: "Se isso ofende o estrangeiro, como não humilha o brasileiro!" (SCHWARZ, 200o, p. 11).

Em semelhante estágio encontra-se o esforço feito pela geração romântica no Brasil: Como construir um discurso de nação calcado em odes ao índio e às belezas naturais frente a um quadro tão dissonante quanto à escravidão? Na literatura, o país que louva o índio é o mesmo que chicoteia o negro.

O silêncio sobre a escravidão ajuda a compreender como o discurso de nação está pautado em um processo de imaginação, tal qual o defendido por Benedict Anderson e corroborado pelas análises de Stuart Hall.

Dessa forma, Eles eram muitos cavalos (2013) irrompe como o exemplo de uma literatura que se contrapõe ao apregoado pelo modelo romântico e põe ênfase justamente nas fissuras que o discurso monolítico da nação apresenta. Por trás da aparente estabilidade de uma representação homogênea feita pela literatura brasileira no Século XIX, Luiz Ruffato expõe, no Século XXI, as mazelas recalcadas por uma pretensa cultura nacional unificada.

Homi Bhabha sugere que "o passado nacional atávico e sua linguagem do pertencer arcaico marginalizam o presente da 'modernidade' da cultura nacional, de certa forma sugerindo que a história acontece 'fora' do centro e do núcleo." (BHABHA, 1998, p. 234).

Se a literatura brasileira ao longo do Século XIX optou por construir um discurso de nação imaginado, suprimindo a heterogeneidade, Ruffato vai à direção contrária, rompe com o estabelecido pela primeira geração romântica da literatura brasileira, e parte de heterogeneidade que existe "fora do centro e do núcleo", conforme a proposição de Bhabha, para desconstruir a ideia de uma cultura nacional uniforme.

\section{Referências}

ANDERSON, B. Nação e consciência nacional. São Paulo: Ática, 1989. 
ASSIS, M. de. Instinto de nacionalidade. Disponível em: <https://edisciplinas.usp.br/pluginfile.php/35508o/mod_resource/content/1/mac hado.\%2oinstinto\%2ode\%2onacionalidade.pdf>. Acesso em: o8 set. 2018.

BELLEI, S. L. P. Nação, DissemiNação e Viagens Antropofágicas. Revista Travessia, Ilha de Santa Catarina, n. 37, p. 45-57, 1998.

BENJAMIN, W. $O$ narrador. Disponível em: <https://pglel.files.wordpress.com/2016/o1/o-narrador.pdf>. Acesso em: o2 dez. 2018.

BHABHA, H. DissemiNação. In. O local da cultura. Belo Horizonte: UFMG, 2010.a CANDIDO, A. Formação da literatura brasileira: momentos decisivos. Belo Horizonte: Itatiaia, 2000.

FREIRE, P. Pedagogia do oprimido. São Paulo: Paz e Terra, 1983.

HALL, S. A identidade cultural na pós-modernidade. Rio de Janeiro: DP\&A, 2006. HOBSBAWM, E. Nações e nacionalismo desde 1780. São Paulo: Paz e Terra, 1990. MAGALHÃES, D. J. G. de. Discurso sobre a história da literatura do Brasil. Disponível em: <http://www.dominiopublico.gov.br/pesquisa/DetalheObraForm.do?select_actio n=\&co_obra=208o $>$. Acesso em: 02 jan. 2019.

RENAN, E. $O$ que é uma nação? Disponível em: <http://www.unicamp.br/ aulas/VOLUMEo1/ernest.pdf>. Acesso em: o8 set. 2018.

RUFFATO, L. Eles eram muitos cavalos. São Paulo: Schwarcz, 2013.

SCHWARZ, R. As ideias fora do lugar. In. Ao vencedor as batatas. São Paulo: Duas cidades/ Editora 34, 2000.

SILVA, F. C. da. Eles eram muitos cavalos: leituras. Breves considerações estéticas e políticas. Revista Crioula, n. 6, 1 nov. 2009.

"Mestrando em Letras na Universidade Federal de Pelotas (UFPEL) na área de Literatura, Cultura e Tradução. 